\title{
Vanadium pentoxide effects on stress responses in wine Saccharomyces cerevisiae strain $\mathrm{UE}-\mathrm{ME}_{3}$
}

\author{
Tânia Rosado • Ana Conim • \\ Isabel Alves-Pereira · Rui Ferreira
}

Accepted: 24 June 2009/Published online: 12 July 2009

(C) Springer Science+Business Media, LLC 2009

\begin{abstract}
Vanadium pentoxide mainly used as catalyst in sulphuric acid, maleic anhydride and ceramics industry, is a pollutant watering redistributed around the environment. Research on biological influence of vanadium pentoxide has gained major importance because it exerts toxic effects on a wide variety of biological systems. In this work we intent to evaluate the effects of vanadium pentoxide ranging from 0 to $2 \mathrm{mM}$ in culture media on a wine wild-type Saccharomyces cerevisiae from Alentejo region of Portugal. Our results show that $2.0 \mathrm{mM}$ vanadium pentoxide in culture medium induced a significant increase of malonaldehyde level and Glutathione peroxidase activity, a slightly increase of Catalase A activity as well as a decrease of wet weight and mitochondrial NADH cit c reductase of $S$. cerevisiae UE-ME ${ }_{3}$. Also our results show that cycloheximide prevent cell death when cells grows $30 \mathrm{~min}$ in presence of $1.5 \mathrm{mM}$ of vanadium pentoxide.
\end{abstract}

Keywords Vanadium - Malonaldehyde $\cdot$ Catalase A . Mitochondrial NADH cit c reductase - Glutathione peroxidase $\cdot$ Saccharomyces cerevisiae

$\begin{array}{ll}\text { Abbreviations } \\ \mathrm{V}_{2} \mathrm{O}_{5} & \text { Vanadium pentoxide } \\ \text { MDA } & \text { Malonaldehyde } \\ \text { CAT A } & \text { Catalase peroxisomal }\end{array}$

T. Rosado · A. Conim · I. Alves-Pereira · R. Ferreira Departamento de Química, Universidade de Évora, R.Romão Ramalho, 59, 7002-671 Évora, Portugal

I. Alves-Pereira $\cdot$ R. Ferreira $(\bowtie)$ Instituto de Ciências Agrárias Mediterrânicas (ICAM) Colégio da Mitra, 7000-083 Évora, Portugal

e-mail: raf@uevora.pt
GPx
Glutathione peroxidase
ROS
Reactive oxygen species

\section{Introduction}

Wine fermentation is a complex ecological and biochemical process involving the sequential development of different yeast species. The non-Saccharomyces yeasts grow well during early stages of fermentation, but are subsequently replaced during the following stages by Saccharomyces yeasts (Fleet and Heard 1992; Pretorius 2000). Traditionally the wine production by natural fermentation is greatly influenced by the yeast resistance to the stress conditions, including the osmotic stress imposed by the high sugar content of the must and the ethanol produced during fermentation, otherwise by pesticides and metals intakes by grapes from the soil or present in winery steel equipment (Bauer and Pretorius 2000; Querol et al. 2003). Vanadium is a rare, soft, ductile grey-white element (Nechay 1984) found combined in certain minerals and used mainly in steel or pesticides production. The level of vanadium occurrence in the earth's crust is around $150 \mathrm{ppm}$. Moreover, Human activities as fuel oil burning, steel empowerment, manufacturing of sulphuric acid and maleic anhydride and pesticide use, increase its environmental level in the air, soil, food and water, reaching in several cases $6,000 \mathrm{ppm}$ (Penuelas and Filella 2002). This metal exhibits a wide range of stable oxidation states, two of which, vanadate $\left(\mathrm{V}^{5+}\right)$, and the less vanadyl $\left(\mathrm{V}^{4+}\right)$, are considered to be predominant in living systems (Bode et al. 1990). It is well known that vanadium exerts toxic, mutagenic, and genotoxic effects on a wide variety of biological systems, inducing alterations of many important metabolic functions 
(Willsky 1990). Moreover, vanadium can be a pollutant in urban, industrial and rural areas, as a consequence of industrial processes or chemical products application, fact which requires the elucidation of the mechanisms by which living organisms, like this wine yeast, answer to the presence of this metal ion in its growth medium during wine fermentation (Mannazzu 2001). Since metals environmental level is an issue of great environmental apprehension, we

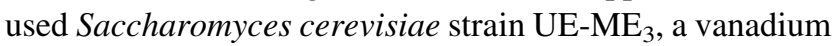
resistant strain (Ferreira et al. 2006), for evaluate the vanadium stress responses in a wine wild-type yeast of Alentejo, a wine region of Portugal, having in account the environmental importance of characterization and preservation of wild-type strains of a winery region. Considering that metals, disturbs energetic metabolism of the cell, which is the main source of endogenous ROS production, mainly at NADH reoxidation mechanisms and fatty acids oxidation, we also intent evaluate how vanadium pentoxide affect several antioxidant responses of yeast cell, since reactive oxygen species has also been identified as essential in yeast cell death (Madeo et al. 1999) and NADH dehydrogenases display the role of regulates apoptosis in yeast ( $\mathrm{Wu}$ et al. 2002; Wissing et al. 2004; Maris et al. 2001; Li et al. 2006). At least five mechanisms of NADH reoxidation exist in S. cerevisiae. These are: (a) alcoholic fermentation; (b) glycerol production; (c) respiration of cytosolic NADH via external mitochondrial NADH dehydrogenases (EC 1.6.5.3, NDE1 and NDE2); (d) respiration of cytosolic NADH via the glycerol-3-phosphate shuttle; and (e) oxidation of intramitochondrial NADH via a mitochondrial 'internal' NADH dehydrogenase (EC 1.6.5.3, NDI). (Luttik et al. 1998; Bakker et al. 2001; Jault et al. 1994; Moore et al. 1992; Crichton et al. 2007; Small and McAlister-Henn 1998; Davidson and Schiestl 2001). Although it has been recognized that peroxisomal structures and a number of their constituent proteins are inducible by lipids or fatty acids, very little is known about the mechanisms involved in induction of peroxisomes in any eucaryotic organism (Lazarow and Fujiki 1985; Lock et al. 1989; Tolbert 1981). Catalase A (EC 1.11.1.6, CAT A) has been demonstrated to be induced by fatty acids together with peroxisomal structures and a number of other peroxisomal proteins (Skoneczny et al. 1988; Veenhuis et al. 1987; Cohen et al. 1985; Cohen et al. 1988). Therefore it should be possible to use the expression of the Cta1 gene as an indicator for the induction or repression of peroxisome formation (Simon et al. 1991). Though it was determined CAT A, a peroxisomal enzyme involved in scavenging of $\mathrm{H}_{2} \mathrm{O}_{2}$ resulting from an eventual increase of mitochondrial free-radical flux induced by vanadium to evaluate the antioxidant response of peroxisomal fraction from lag yeast cells. In other hand, glutathione peroxidase (GPx) an enzyme of redox cycle of glutathione is expressed in yeast cells and plays a crucial role in the defence line against ROS (Izawa et al. 1995) under $S$. cerevisiae reducing $\mathrm{H}_{2} \mathrm{O}_{2}$ endogenously formed, as well as, $\mathrm{LOOH}$ to $\mathrm{H}_{2} \mathrm{O}$ and corresponding alcohol (Inoue et al. 1999). Given that mitochondrial electron transport is a large contributor to oxidative stress, we have investigated how vanadium pentoxide influence yeast mitochondrial $\mathrm{NADH}$ dehydrogenases, using $\mathrm{NADH}$ cytochrome $\mathrm{c}$ reductase activity as marker, CAT A, and GPx as peroxisomal and cytoplasmactic enzymes markers of antioxidant response, as well as cytoplasmatic malonaldehyde generation during metal exposition assays to determine yeast cell damages caused by vanadium pentoxide. In addition, we attempt to determine if cycloheximide, a protein synthesis inhibitor, revert an eventual yeast growth inhibition caused by $1.5 \mathrm{and} /$ or $2.0 \mathrm{mM} \mathrm{V}_{2} \mathrm{O}_{5}$ and infer an eventual apoptosis process (Ludovico et al. 2003), which can be correlate with events involving mitochondria and peroxisomes.

\section{Materials and methods}

\section{Microorganisms and growth conditions}

The eukaryotic model used was the wine wild-type Saccharomyces cerevisiae $\mathrm{UE}-\mathrm{ME}_{3}$, a strain isolated from regional wine (Alentejo-Portugal), belonging to the Enology laboratory collection of University of Évora, a greatly resistant strain to metal stress (Ferreira et al. 2006). The isolated colonies of this strain were stored in glycerol $(30 \%, w / v)$ at $-80^{\circ} \mathrm{C}$. The cells were grown to midexponential phase in a water bath, with orbital stirring, at $28^{\circ} \mathrm{C}$, in $250-\mathrm{ml}$ flasks containing $100 \mathrm{ml}$ of YEPD medium with $2 \%(\mathrm{w} / \mathrm{v})$ of glucose (Atlas 2006). The cells $\left(10^{6}\right.$ cells $\left.\mathrm{ml}^{-1}\right)$ at mid-exponential phase were inoculated in the same condition and incubated during $200 \mathrm{~min}$ at $28^{\circ} \mathrm{C}$ in the absence or presence of 1.5 and $2.0 \mathrm{mM} \mathrm{V}_{2} \mathrm{O}_{5}$.

At the end of the experiment, samples from each treatment were used for biomass determination by wet weight. The cultures were used to obtain the peroxisomes enriched fraction, and mitochondria enriched fraction, as well as, post-peroxisomal supernatant which were used for determination of CAT A; mitochondrial NADH cit C reductase; GPx and Malondialdehyde (MDA) level, respectively.

Inhibition of protein synthesis

The effect of protein synthesis inhibition was also evaluated determining the dose-response curves in liquid medium and yeast growth in solid medium: Exponential-phase cells were harvest, suspended and grown at $28^{\circ} \mathrm{C}$ in liquid $2 \%$ glucose YEPD medium, containing $\mathrm{V}_{2} \mathrm{O}_{5}$ at $0,1.5$ and $2.0 \mathrm{mM}$ and cycloheximide $50 \mathrm{mg} / \mathrm{ml}$ for $30 \mathrm{~min}$. At the same time and conditions was performed a control assay 
without cycloheximide. Samples from each treatment were diluted and plated in triplicate on YEPD medium, in order to obtain viable counts (cfu) and to observe the effect of protein synthesis inhibition (Ludovico et al. 2003; Matsuyama et al. 1998).

\section{Preparation of peroxisomes enriched fraction}

Peroxisomes enriched fraction was obtained by a modification of the procedure of Petrova et al. (2004). Cells growing in YEPD medium with $2 \%(\mathrm{w} / \mathrm{v})$ of glucose and, incubated during $200 \mathrm{~min}$ at $28^{\circ} \mathrm{C}$, in the absence or presence of 1.5 and $2.0 \mathrm{mM} \mathrm{V} \mathrm{O}_{5}$ were harvested and ultra-sonic disrupt in chilled lysis buffer $(0.2 \mathrm{M}$ sorbitol, $20 \mathrm{mM}$ HEPES-KOH $\mathrm{pH}$ 7.0, $50 \mathrm{mM}$ potassium acetate, $2 \mathrm{mM}$ EDTA). The resulting extracts were differentially centrifuged at $3,000 \mathrm{~g}, 4^{\circ} \mathrm{C}, 10 \mathrm{~min}$, and at $12,000 \mathrm{~g}, 4^{\circ} \mathrm{C}$, $30 \mathrm{~min}$. The crude organelle fraction obtained from this centrifugation was suspended in $50 \mathrm{mM}$ phosphate buffer $\mathrm{pH} 7.5$ at a protein concentration of $150 \mu \mathrm{g}$ per $\mathrm{ml}$.

Preparation of mitochondria enriched fraction

Mitochondria enriched fraction was obtained by a modification of the procedure of Tzagoloff (1971). Cells growing in YEPD medium with $2 \%(\mathrm{w} / \mathrm{v})$ of glucose and incubated during $200 \mathrm{~min}$ at $28^{\circ} \mathrm{C}$ in the absence or presence of 1.5 and $2.0 \mathrm{mM} \mathrm{V} \mathrm{O}_{5}$ were harvested and suspended in a medium consisting of $0.25 \mathrm{M}$ mannitol, 0.05 M Tris-acetate, $\mathrm{pH} 7.5$, and $1 \mathrm{mM}$ EDTA (MTE) at a concentration of $1-5 \mathrm{~g}$, wet weight, per $30 \mathrm{ml}$ of medium. The suspension $(2.5 \mathrm{ml})$ was mechanical homogenized with $1 \mathrm{ml}$ of glass beads (0.45-0.50 $\mathrm{mm}$ diameter) for $45 \mathrm{~s}$. The homogenate was centrifuged at $800 \mathrm{~g}$ for $20 \mathrm{~min}$. The supernatant was centrifuged at $12,000 \mathrm{~g}$ for $30 \mathrm{~min}$. The mitochondria enriched fraction obtained was suspended in a solution containing $0.25 \mathrm{M}$ sucrose and 0.01 M Tris-acetate, $\mathrm{pH} 7.5$, concentration of $200 \mu \mathrm{g}$ per $\mathrm{ml}$. All steps were carried out at $0-4^{\circ} \mathrm{C}$.

Malonaldehyde and protein determination

The obtained post-peroxisomal supernatant was used for malonaldehyde determination (MDA, nmol/mg wet weight) as an index of lipid peroxidation according to the spectrofluorometric method of Uchiyama and Mihara (1978) and Kitamura et al. (2006). In brief, $0.05 \mathrm{ml}$ of post-peroxissomal supernatant, $0.2 \mathrm{ml}$ of $8.1 \%$ SDS and $3.0 \mathrm{ml}$ of $0.4 \%$ thiobarbiturate in $10 \%$ acetic acid solution $(\mathrm{pH} 3.5)$ were added and heated in a water bath at $95^{\circ} \mathrm{C}$ for $60 \mathrm{~min}$. After cooling, $5.0 \mathrm{ml}$ of $n$-butanol and $1.0 \mathrm{ml}$ distilled water were added to the sample, which was centrifuged at 3,000 rpm for $10 \mathrm{~min}$. The fluorescence of TBARS was determined in the butanol phase at $553 \mathrm{~nm}$ using a single beam Shimadzu RF-5001 PC spectrofluorophotometer with the excitation at $515 \mathrm{~nm}$. MDA was prepared by hydrolysis of 1,1,3,3-tetraethoxypropane $(10 \mathrm{mmol}$; Aldrich) by $\mathrm{HCl}(10 \mathrm{ml}$, $100 \mathrm{mM}$ ) in a total volume of $50 \mathrm{ml}$ at $60^{\circ} \mathrm{C}$ for $1 \mathrm{~h}$. A series of MDA standards ranging from 2.5 to $100 \mu \mathrm{M}$ were treated like de samples and used to prepare a standard calibration curve. The solutions were stored at $4^{\circ} \mathrm{C}$ and assayed spectrofluorophotometrically immediately prior to use.

Protein concentration was determined according to Lowry et al. (1951) using BSA as standard.

\section{Enzymatic assays}

CAT A activity was determined by measuring the decrease in absorbance at $240 \mathrm{~nm}$ due to $\mathrm{H}_{2} \mathrm{O}_{2}$ consumption according to Beers and Sizer (1952). The reaction mixture consisted of: $30 \mathrm{mM} \mathrm{H} \mathrm{O}_{2}$ and adequate concentration of peroxisomal pellet $(\sim 5 \mu \mathrm{g}$ per $\mathrm{ml})$ in $50 \mathrm{mM}$ phosphate buffer $\mathrm{pH} 7.5$.

$\mathrm{NADH}$-cytochrome $c$ reductase activity was determined in mitochondria enriched fraction $\left(\sim 15 \mu \mathrm{g}\right.$ per ml) at $30^{\circ} \mathrm{C}$ in $10 \mathrm{mM} \mathrm{K}_{2} \mathrm{HPO}_{4}$, pH 7.5, containing $100 \mu \mathrm{M} \mathrm{KCN}$ by following the reduction of Cyt $\mathrm{C}(22.5 \mu \mathrm{M})$ at $550 \mathrm{~nm}$ in the presence of $0.5 \mathrm{mM} \mathrm{NADH}$, according to Tzagoloff et al. (1975) and Ludovico et al. (2002).

GPx activity in post-peroxissomal supernatant were assayed in reaction buffer comprised of $100 \mathrm{mM}$ phosphate pH 7.0, 5 mM EDTA, $1.60 \mathrm{mM}$, NADPH, $5.0 \mathrm{mM} \mathrm{GSH}$ and $0.24 \mathrm{U}$ glutathione reductase. Post-peroxissomal supernatant in adequate dilution $(25 \mu \mathrm{g}$ per $\mathrm{ml})$ was added to $1 \mathrm{ml}$ of total volume. The reaction mixture was preincubated for $10 \mathrm{~min}$ to $37^{\circ} \mathrm{C}$ with continuous stirring. After the addition of NADPH, the decay of the absorbance at $340 \mathrm{~nm}$ was followed for $3 \mathrm{~min}$ to obtain a line of control test. The overall reaction was then initiated by addition of $1.0 \mathrm{mM}$ of $\mathrm{t}-\mathrm{BHP}$, preheated to $37^{\circ} \mathrm{C}$ and the decrease in absorption at $340 \mathrm{~nm}$ was monitored for $5 \mathrm{~min}$ according to standard protocols (Chaudiere et al. 1984; Flohé and Gunzler 1984). The rate of reaction depends on GPx was obtained when the effects of independent and non-enzymatic hydroperoxide were subtracted from the total rate of reaction, according to descriptions in literature (Flohé and Gunzler 1984). As GSH was continuously regenerated by glutathione reductase, the concentration of GSH in the trial was held in the initial level. Consequently, the GPx reaction proceeds in accordance with an order kinetics of pseudo-zero. To calculate enzymatic activity, it was used the coefficient of molar extinction 6.22 $\mathrm{mM}^{-1} \mathrm{~cm}^{-1}$ of NADPH $+\mathrm{H}^{+}$(Holme and Peck 1993).

Protein and all enzymatic measurements were carried out with a double beam spectrophotometer, Hitachi-U2001 with temperature control. 
Statistical analysis

All the data presented are mean values achieved in five independent experiments \pm SD. The normality and homogeneity of variance were assessed by the P-Plot and Levene's test, respectively. The statistical analysis of results were performed by ANOVA I and Dunett's test to determine significant differences $(P<0.01)$ between treatments, using SPSS for windows, version 16, licensed to University of Évora (Sokal and Rohlf 1997).

\section{Results}

In this work we have been studied the stress response to vanadium pentoxide a pollutant resulting from chemical industry like, sulphuric acid and pesticides production or ceramic making processes, using a wine wild-type yeast of Alentejo region of Portugal. Figure 1 shows a significantly decrease of biomass production for $200 \mathrm{~min}$ by wine Saccharomyces cerevisiae $\mathrm{UE}-\mathrm{ME}_{3}$ cultures exposed to $\mathrm{V}_{2} \mathrm{O}_{5}(P<0.01)$, occurring a decline of 19 and $53 \%$ of wet weight for cells growing in culture medium with 1.5 and $2.0 \mathrm{mM} \mathrm{V} \mathrm{V}_{2} \mathrm{O}_{5}$, respectively. This fact appoints us vanadium pentoxide, in this range concentration, as a potent growth inhibitor of this wild-type yeast $S$. cerevisiae.

In order to evaluate the effects of vanadium pentoxide on de novo protein synthesis, the dose-response curves were determined, growing yeast cells in liquid medium containing $\mathrm{V}_{2} \mathrm{O}_{5}$ at $0,1.5$ and $2.0 \mathrm{mM}$ with or without cycloheximide $50 \mathrm{mg} / \mathrm{ml}$ for $30 \mathrm{~min}$, plating samples from each treatment on YEPD medium and counting colony forming units (cfu) in solid medium. Figure 2 shows that these concentration of cycloheximide is not cytotoxic after 30 min incubation and increased cell viability in cultures

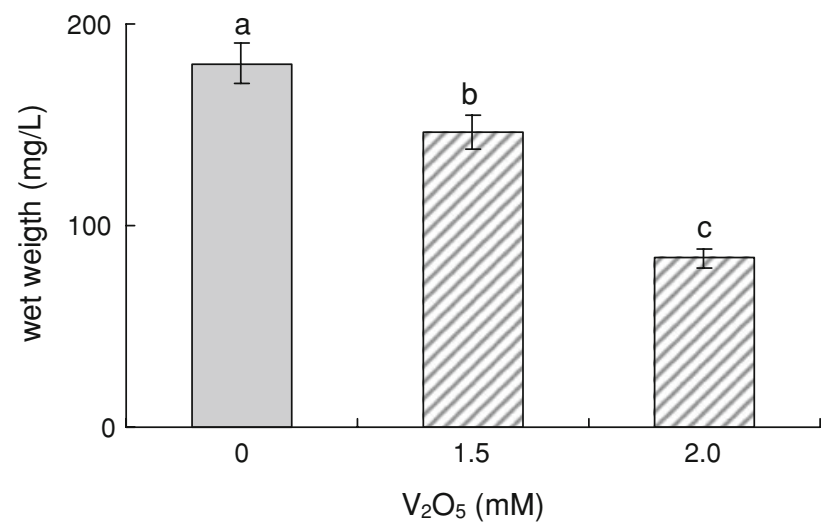

Fig. 1 Effect of $\mathrm{V}_{2} \mathrm{O}_{5}$ on biomass production for $200 \mathrm{~min}$ by wine wild-type Saccharomyces cerevisiae $\mathrm{UE}-\mathrm{ME}_{3}$ cell. Each bar represents the mean $\pm \mathrm{SD}$ of five independents experiments (bars with no common letter are significantly different, $P<0.01$ ) treated with $1.5 \mathrm{mM}$ vanadium pentoxide, whereas for $2.0 \mathrm{mM} \mathrm{V}_{2} \mathrm{O}_{5}$ occur a reverse response.

Having in account that oxidative damages resulting from ROS formation in metal stress conditions and a subsequent fail of antioxidant and energetic mechanisms of the cell will be implicated in cell death, it was also select as a significant goal of this study to prospect the possibility of MDA level of the cell, antioxidant peroxisomal catalase, mitochondrial NADH cytochrome $\mathrm{c}$ reductase and glutathione peroxidase activities of wine wild-type yeast Saccharomyces cerevisiae UE-ME $\mathrm{M}_{3}$ will be used as biomarkers of vanadium toxicity.

Figure 3 shows that yeast cells growing in presence of vanadium pentoxide have got an high significantly increase of MDA level $(P<0.01)$ with values 19 - and 52-fold higher than control, for 1.5 and $2.0 \mathrm{mM} \mathrm{V}_{2} \mathrm{O}_{5}$, respectively.

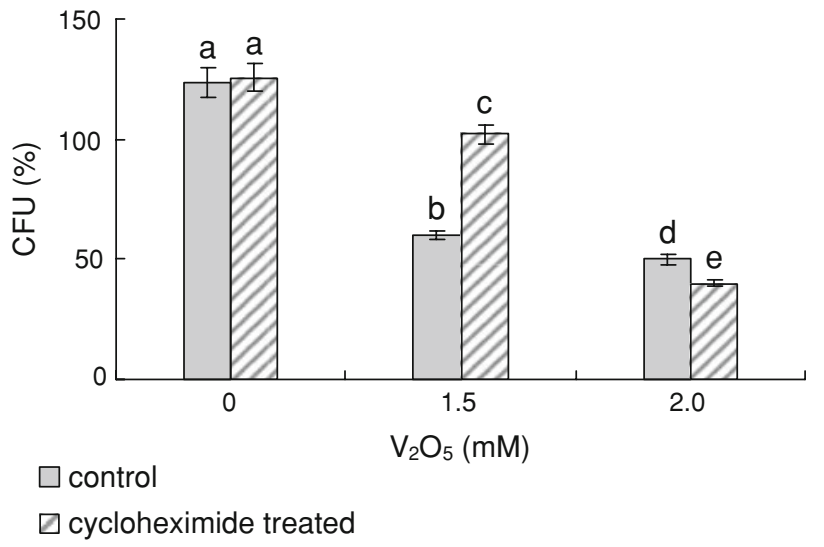

Fig. 2 Relative survival (\% cfu) of wine wild-type Saccharomyces cerevisiae $\mathrm{UE}-\mathrm{ME}_{3}$, for $30 \mathrm{~min}, \mathrm{~V}_{2} \mathrm{O}_{5} 0,1.5$ and $2.0 \mathrm{mM}$ in the absence or presence of cycloheximide. Each bar represents the mean of five independent experiments (bars with no common letter are significantly different, $P<0.01$ )

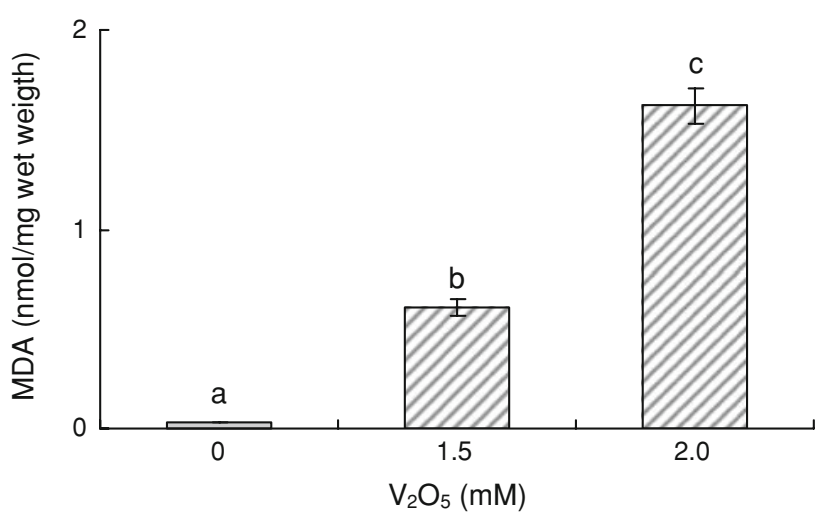

Fig. 3 Effect of $\mathrm{V}_{2} \mathrm{O}_{5}$ on MDA level of wine wild-type Saccharomyces cerevisiae $\mathrm{UE}-\mathrm{ME}_{3}$. Each bar represents the mean $\pm \mathrm{SD}$ of five independents experiments (bars with no common letter are significantly different, $P<0.01$ ) 
Figure 4 only shows an increase of antioxidant CAT A activity for the treatment with $2.0 \mathrm{mM} \mathrm{V} \mathrm{O}_{5}$, but without statiscal significance.

Figure 5 shows a significantly decrease of mitochondrial NADH cyt $\mathrm{C}$ reductase in both vanadium pentoxide treatments, occurring a decline of 30 and $33 \%$ for 1.5 and $2.0 \mathrm{mM} \mathrm{V}_{2} \mathrm{O}_{5}$ in culture medium.

Figure 6 shows a significantly and reverse increase of glutathione peroxidase in $S$. cerevisae $\mathrm{UE}-\mathrm{ME}_{3}$ grown in presence of vanadium pentoxide, occurring a raise of $3,5 \times$ and $2 \times$ for 1.5 and $2.0 \mathrm{mM} \mathrm{V}_{2} \mathrm{O}_{5}$ in culture medium, respectively.

\section{Discussion}

The aim of this study was to evaluate the effect of 1.5 and $2.0 \mathrm{mM}$ vanadium pentoxide on cell growth, de novo

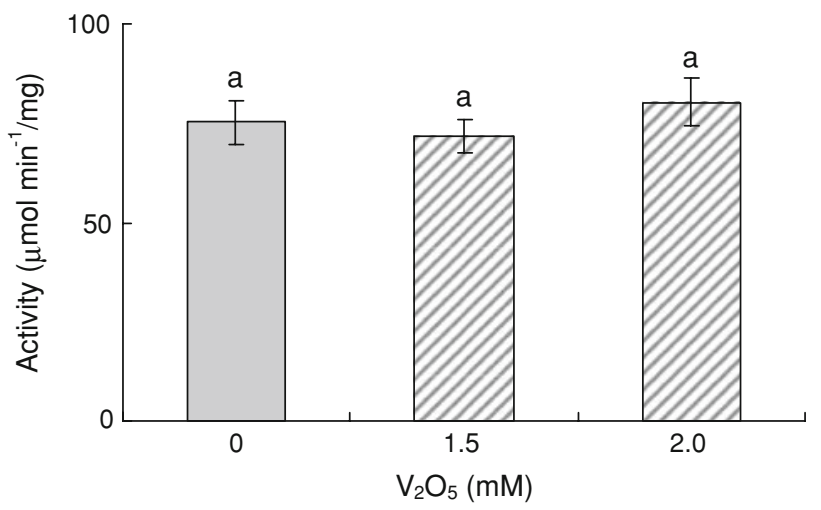

Fig. 4 Effect of $\mathrm{V}_{2} \mathrm{O}_{5}$ on CAT A activity of wine wild-type

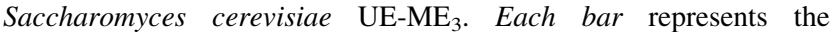
mean $\pm \mathrm{SD}$ of five independents experiments (bars with no common letter are significantly different, $P<0.01$ )

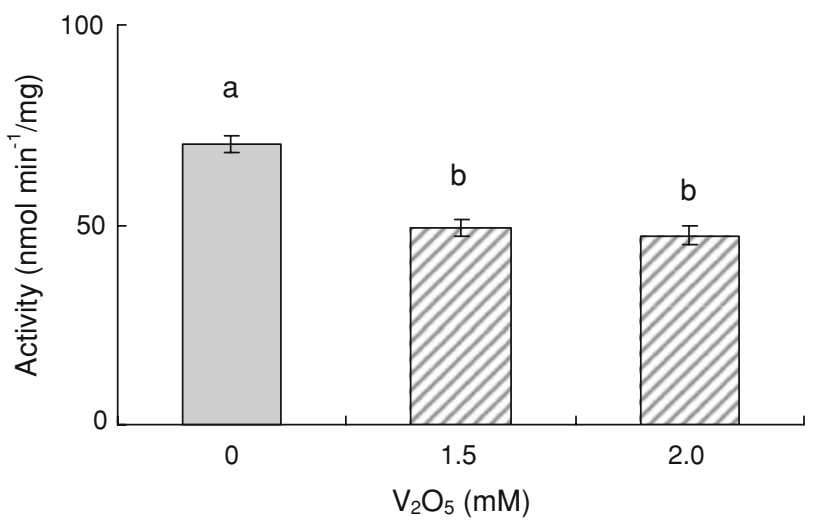

Fig. 5 Effect of $\mathrm{V}_{2} \mathrm{O}_{5}$ on mitochondrial NADH cyt $\mathrm{C}$ reductase activity of wine wild-type Saccharomyces cerevisiae $\mathrm{UE}^{-\mathrm{ME}_{3}}$. Each bar represents the mean $\pm \mathrm{SD}$ of five replicates (bars with no common letter are significantly different, $P<0.01$ )

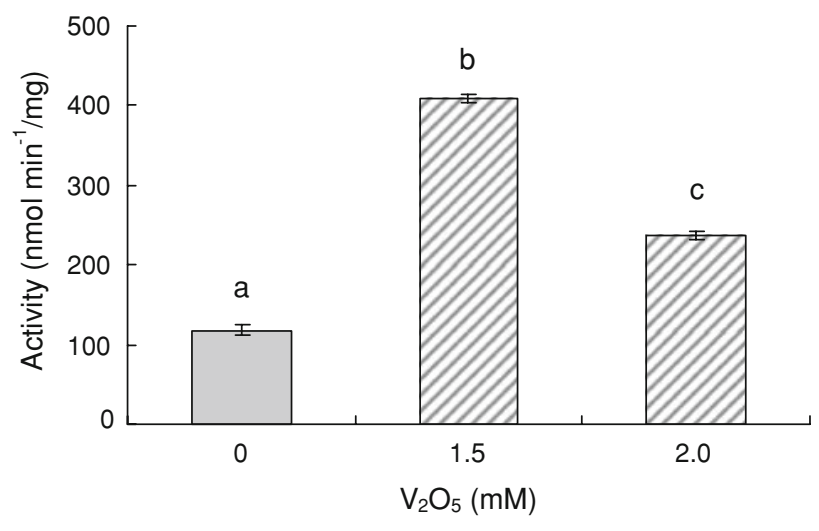

Fig. 6 Effect of $\mathrm{V}_{2} \mathrm{O}_{5}$ on GPx activity of wine wild-type Saccharo-

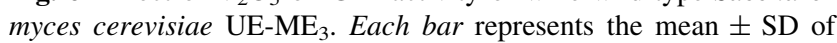
five replicates (bars with no common letter are significantly different, $P<0.01)$

protein synthesis, lipid peroxidation, catalase A, mitochondrial NADH cytochrome $\mathrm{C}$ reductase and cytosolic glutathione peroxidase activities of wild-type wine yeast

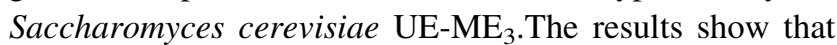
vanadium pentoxide is a potent growth inhibitor of wine

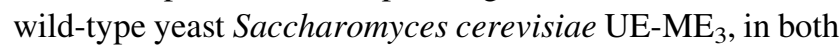
concentration assayed (Fig. 1). In order to address the question if the cell death process, induced in S. cerevisiae UE- $\mathrm{ME}_{3}$ by vanadium pentoxide, is an active process, which is characteristic of apoptosis (Ludovico et al. 2002), we analysed the dependence of the vanadium pentoxide induced yeast killing on de novo protein synthesis. The presence of cycloheximide attenuated the toxic effect of $1.5 \mathrm{mM}$ vanadium pentoxide, increasing cell viability of yeast exposed $30 \mathrm{~min}$ to $1.5 \mathrm{mM}$ vanadium pentoxide, an indication that such cell death is an active process (Fig. 2). During oxidative stress, a proportion of the ROS evades the host defences and can cause oxidative damage to nucleic acids, lipids, and proteins (Halliwell 1991; Kappus 1987; Sies and de Groot 1992). As a result of the oxidative damage to lipids, a variety of lipid hydroperoxides are formed, whose subsequent breakdown products may well be just as toxic as the ROS themselves (Esterbauer 1993). MDA is a commonly detected aldehyde (Esterbauer et al. 1991; Steels et al. 1994) which has been used as a measure of lipid peroxidation (Turton et al. 1997). Consequently, the highly significant increase of MDA level detected in yeast cells grown in presence of vanadium pentoxide (Fig. 3) advise that oxidative damages caused by ROS (Cabiscol et al. 2000), linked to an approximately null response of CAT A (Fig. 4) and a reverse increase of GPx (Fig. 6) to lipid peroxides stress, are also implicated in S. cerevisiae UE-ME $\mathrm{ME}_{3}$ growth inhibition. This response is correlate with loss of vital functions, like cytotoxic inhibition of mitochondrial dehydrogenases (Fig. 5), which block cytosolic 
NADH reoxidation with disturb of energetic metabolism of the $S$. cerevisiae UE-ME $\mathrm{ME}_{3}$ cells, generating ROS, like is described by several authors (Herrero et al. 2008; Sedensky and Morgan 2006; Wang et al. 2004; Davidson and Schiestl 2001; Overkamp et al. 2000). Bearing in mind that cytosolic ROS, namely hydrogen peroxide and/or lipid peroxides can be implicated in the yeast cell death (Madeo et al. 2002), we presume that oxidative stress generate by $1.5 \mathrm{mM}$ vanadium pentoxide can cause apoptosis in $S$. cerevisiae UE-ME $E_{3}$. Additionally we also suppose that yeast MDA levels and mitochondrial dehydrogenases activity can be sensitive markers of vanadium toxicity.

Acknowledgments We acknowledge to "Instituto de Ciências Agrárias e Ambientais Mediterrânicas" (ICAM) at University of Évora, Portugal, by financial support of this work. We thanks to Eng ${ }^{\circ}$ Paulo Laureano of the Laboratory of Enology of University of Évora for the yielding of the yeast strain.

\section{References}

Atlas RM (2006) Handbook of microbiological media for the examination of food, 2nd edn. CRC/Taylor \& Francis, Boca Raton, p 403

Bakker BM, Overkamp KM, Maris AJA, Kotter P, Luttik MAH, Dijken JPD, Pronk JT (2001) Stoichiometry and compartmentation of NADH metabolism in Saccharomyces cerevisiae. FEMS Microbiol Rev 25:15-37

Bauer FF, Pretorius IS (2000) Yeast stress response and fermentation efficiency: how to survive the making of wine-a review. South African J Enol Vit 21:27-51

Beers RF, Sizer JW (1952) A spectrophotometric method for measuring the breakdown of hydrogen peroxide by catalase. J Biol Chem 195:133-138

Bode HP, Friebel C, Fuhrmann GF (1990) Vanadium uptake by yeast cells. Biochim Biophys Acta 1022:163-170

Cabiscol E, Piulats E, Echave P, Herrero E, Ros J (2000) Oxidative stress promotes specific protein damage in Saccharomyces cerevisiae. J Biol Chem 275:27393-27398

Chaudiere J, Wilhelmsen EC, Tappels AL (1984) Mechanism of selenium-glutathione peroxidase and its inhibition by mercaptocarboxylic acids and other mercaptans. J Biol Chem 259: 1043-1050

Cohen G, Fessl F, Traczyk A, Rytka J, Ruis H (1985) Isolation of the catalase A gene of Saccharomyces cerevisiae by complementation of the ctal mutation. Mol Gen Genet 200:74-79

Cohen G, Rapatz W, Ruis H (1988) Sequence of the Saccharomyces cerevisiae CTA1 gene and amino acid sequence of catalase A derived from it. Eur J Biochem 176:159-163

Crichton PG, Affourtit C, Moore AL (2007) Identification of a mitochondrial alcohol dehydrogenase in Schizosaccharomyces pombe: new insights into energy metabolism. Biochem $\mathrm{J}$ 401:459-464

Davidson JF, Schiestl RH (2001) Mitochondrial respiratory electron carriers are involved in oxidative stress during heat stress in Saccharomyces cerevisiae. Mol Cell Biol 21:8483-8489

Esterbauer H (1993) Cytotoxicity and genotoxicity of lipid-oxidation products. Am J Clin Nutr 57:779S-786S

Esterbauer H, Schaur RJ, Zollner H (1991) Chemistry and biochemistry of 4-hydroxynonenal, malondialdehyde and related aldehydes. Free Rad Biol Med 11:81-128
Ferreira R, Alves-Pereira I, Magriço S, Ferraz-Franco C (2006) Comparative effects of $\mathrm{NH}_{4} \mathrm{VO}_{3}$ on detoxication enzymes and redox state of wine Saccharomyces. In: Collery P (ed) Metal ions in biology and medicine, vol 9. John Libbey Eurotext, Paris, pp $169-174$

Fleet H, Heard GM (1992) Yeast-growth during fermentation. In: Fleet $\mathrm{H}$ (ed) Wine microbiology and biotechnology. Harwood Academic Publishers, Chur, pp 27-54

Flohé L, Gunzler WA (1984) Assay of glutathione peroxidase. Methods Enzymol 105:114-121

Halliwell B (1991) Reactive oxygen species in living systems: source, biochemistry, and role in human disease. Am J Med 91:3C-14S$3 \mathrm{C}-38 \mathrm{~S}$

Herrero E, Ros J, Belli G, Cabiscol E (2008) Redox control and oxidative stress in yeast cell. Biochim Biophys Acta 1780:12171235

Holme DJ, Peck H (1993) Enzymes. In: Holme DJ (ed) Analytical biochemistry, 2nd edn. John Wiley \& Sons, New York, pp 261-318

Inoue Y, Matsuda T, Sugiyama KI, Izawa S, Kimura A (1999) Genetic analysis of glutathione peroxidase in oxidative stress response of Saccharomyces cerevisiae. J Biol Chem 274:2700227009

Izawa S, Inoue Y, Kimura A (1995) Oxidative stress response in yeast: effect of glutathione on adaptation to hydrogen peroxide stress in Saccharomyces cerevisiae. FEBS Lett 368:73-76

Jault JM, Comte J, Gautheron DC, Dipietro A (1994) Preparation of highly phosphorylating mitochondria from the yeast Schizosaccharomyces pombe. J Bioenerg Biomembr 26:447-456

Kappus H (1987) A survey of chemicals inducing lipid peroxidation in biological systems. Chem Phys Lipids 45:105-115

Kitamura Y, Umemura T, Okazaki K, Kankil K, Imazawa T, Masegi T, Nishikawa A, Hirose M (2006) Enhancing effects of simultaneous treatment with sodium nitrite on 2-amino 3 methylimidazo[4,5-f]quinoline-induced rat liver, colon and Zymbal's gland carcinogenesis after initiation with diethylnitrosamine and 1,2-dimethylhydrazine. Int J Cancer 118:2399-2404

Lazarow PB, Fujiki Y (1985) Biogenesis of peroxisomes. Annu Rev Cell Biol 1:489-530

Li W, Sun L, Liang Q, Wang J, Mo W, Zhou B (2006) Yeast AMID homologue Ndilp displays respiration restricted apoptotic activity and is involved in chronological aging. Mol Biol Cell 17:1802-1811

Lock EA, Mitchell AM, Elcombe CR (1989) Biochemical mechanisms of induction of hepatic peroxisome proliferation. Annu Rev Pharmacol Toxicol 29:145-163

Lowry OH, Rosenbrough NJ, Farr L, Randall RJ (1951) Protein measure with de folin phenol reagent. J Biol Chem 193:265-275

Ludovico P, Rodrigues F, Almeida A, Silva MT, Barrientos A, CôrteReal M (2002) Cytochrome $c$ release and mitochondria involvement in programmed cell death induced by acetic acid in Saccharomyces cerevisiae. Mol Biol Cell 13:2598-2606

Ludovico P, Sansonetty F, Silva MT, Côrte-Real M (2003) Acetic acid induces a programmed cell death process in the food spoilage yeast Zygosaccharomyces bailii. FEMS yeast research 3:91-96

Luttik MA, Overkamp KM, Kotter P, Vries S, Dijken JP, Pronk JT (1998) The Saccharomyces cerevisiae NDE1 and NDE2 genes encode separate mitochondrial NADH dehydrogenases catalyzing the oxidation of cytosolic NADH. J Biol Chem 273:2452924534

Madeo F, Fröhlich E, Ligr M, Grey M, Sigrist SJ, Wolf DH, Fröhlich KU (1999) Oxygen stress: a regulator of apoptosis in yeast. J Cell Biol 145:757-767

Madeo F, Engelhardt S, Herker E, Lehman N, Maldener C, Proksch A, Wissing S, Frohlich KU (2002) Apoptosis in yeast: a new 
model system with applications in cell biology and medicine. Curr Genet 41:2008-2216

Mannazzu I (2001) Vanadium detoxification and resistance in yeast: a minireview. Ann Microbiol 51:1-9

Maris AF, Assumpcao AL, Bonatto D, Brendel M, Henriques JA (2001) Diauxic shift-induced stress resistance against hydroperoxides in Saccharomyces cerevisiae is not an adaptive stress response and does not depend on functional mitochondria. Curr Genet 9:137-149

Matsuyama S, Xu Q, Velours J, Red JC (1998) Mitochondrial F0F1ATPase proton-pump is required for function of pro-apoptotic protein Bax in yeast and mammalian cells. Mol Cell 1:327-336

Moore AL, Walters AJ, Thorpe J, Fricaud AC, Watts FZ (1992) Schizosaccharomyces pombe mitochondria: morphological, respiratory and protein import characteristics. Yeast 8:923-933

Nechay BR (1984) Mechanisms of action of vanadium. Annu Rev Pharmacol Toxicol 24:501-524

Overkamp KM, Baker BM, Kotter P, van Tuijl A, de Vries S, van Dijken JO, Pronk JT (2000) In vivo analysis of the mechanisms for oxidation of cytosolic NADH by Saccharomyces cerevisiae mitochondria. J Bacteriol 182:2823-2830

Penuelas J, Filella I (2002) Metal pollution in Spanish terrestrial ecosystems during twentieth century. Chemosphere 46:501-505

Petrova VY, Drescher D, Kujumdzieva AV, Schmitt MJ (2004) Dual targeting of yeast catalase A to peroxisomes and mitochondria. Biochem J 380:393-400

Pretorius IS (2000) Tailoring wine yeast for the new millennium: novel approaches to the ancient art of winemaking. Yeast 16:675-729

Querol A, Fernández-Espinar MT, Olmo M, Barrio E (2003) Adaptative evolution of wine yeast. Int J Food Microbiol 86:3-10

Sedensky MM, Morgan PG (2006) Mitochondrial respiration and reactive oxygen species in mitochondrial aging mutants. Exp Geront 41:237-245

Sies H, de Groot H (1992) Role of reactive oxygen species in cell toxicity. Toxicol Lett 64-65:547-551

Simon M, Adam G, Rapatz W, Spevak W, Ruis H (1991) The Saccharomyces cerevisiae ADRI gene is a positive regulator of transcription of genes encoding peroxisomal proteins. Mol Cel Bio 11:699-704
Skoneczny M, Chelstowska A, Rytka J (1988) Study of the conduction by fatty acids of catalase A and acyl-CoA oxidase. Eur J Biochem 174:297-302

Small WC, McAlister-Henn L (1998) Identification of a cytosolically directed NADH dehydrogenase in mitochondria of Saccharomyces cerevisiae. J Bacteriol 180:4051-4055

Sokal RR, Rohlf FJ (1997) Biometry. W. H. Freeman, New York

Steels EL, Learmonth RP, Watso K (1994) Stress tolerance and membrane lipid unsaturation in Saccharomyces cerevisiae grown aerobically or anaerobically. Microbiology 140:569-576

Tolbert NE (1981) Metabolic pathways in peroxisomes and glyoxysomes. Annu Rev Biochem 50:133-157

Turton HE, Dawes IW, Grant CM (1997) Saccharomyces cerevisiae exhibits a yAP-1-mediated adaptive response to malondialdehyde. J Bacteriol 179:1096-1101

Tzagoloff A (1971) Assembly of the mitochondrial membrane system. IV Role of mitochondrial and cytoplasmic protein synthesis in the biosynthesis of the rutamycin-sensitive adenosine triphosphate. J Biol Chem 246:3050-3056

Tzagoloff A, Akai A, Needleman RB (1975) Assembly of the mitochondrial membrane system. Characterization of nuclear mutants of Saccharomyces cerevisiae with defects in mitochondrial ATPase and respiratory enzymes. J Biol Chem 250:8228-8235

Uchiyama M, Mihara M (1978) Determination of malonaldehyde precursor in tissue by the thiobarbituric acid test. Anal Biochem 86:271-278

Veenhuis M, Mateblowski M, Kunau WH, Harder W (1987) Proliferation of microbodies in Saccharomyces cerevisiae. Yeast 3:77-84

Wang Y, Fang J, Leonard SS, Rao KM (2004) Cadmium inhibits the electron transfer chain and induces reactive oxygen species. Free Rad Biol Med 36:1434-1443

Willsky GR (1990) Vanadium in the biosphere. In: Chasteen ND (ed) Vanadium in biological systems. Kluwer, Netherlands, pp 1-24

Wissing S et al (2004) An AIF orthologue regulates apoptosis in yeast. J Cell Biol 166:969-974

Wu M, Xu LG, Li X, Zhai Z, Shu HB (2002) AMID, an apoptosisinducing factor-homologous mitochondrion-associated protein, induces caspase-independent apoptosis. J Biol Chem 277:25617-25623 